\title{
7. "Tired for nothing"? Women, Chiefs, and the Domestication of Customary Authority in Solomon Islands
}

\author{
Debra McDougall \\ The University of Western Australia
}

\section{Introduction}

Throughout Asia and the Pacific, Christian missionaries were central agents in promulgating an ideal of domesticity that defined a woman's place as in the home. As other chapters in this volume show, however, many European missionary women moved away from hearth and home and led prominent public lives contravening in practice what they endorsed in principle. European women and indigenous women were often present on the mission stations of the Western Pacific, albeit in secondary roles as the wives of male missionaries and converts. The same cannot be said for centres of colonial administration. As Anne Dickson-Waiko has pointed out for colonial Papua New Guinea (PNG), administrative centres were virtually all-male enclaves: European men often left their wives and families back home and indigenous men performed the domestic work that was considered to be women's work by both colonised and colonisers. ${ }^{1}$ The gender segregation of the colonial enclave was, if anything, more pronounced than that of indigenous societies of the region, some of which are famed for "sexual antagonism." The exclusion of women from administrative centres was not accidental, but part of a late colonial strategy to prevent the native people from settling in these colonial enclaves. Keeping women in villages ensured that men would return there when their labour was no longer required, that wages would not have to be high enough to support whole families, and that labour would be available for the rural cash cropping that was the heart of the economy. Such strategies increased the burden on women, who took up the subsistence work of absent men. "A new layer of patriarchy" was thus imposed upon existing indigenous forms of male domination. ${ }^{2}$

\footnotetext{
1 Anne Dickson-Waiko, "Colonial enclaves and domestic spaces in British New Guinea," in Britishness Abroad: Transnational Movements and Imperial Cultures, ed. Kate Darian-Smith, Patricia Grimshaw and Stuart Macintyre, Carlton: Melbourne University Publishing, 2007, pp. 205-30.

2 Dickson-Waiko, “Colonial enclaves and domestic spaces in British New Guinea," p. 206.
} 
Advocates of women's human rights globally often treat localised "custom" or "tradition" as little more than an obstacle to be overcome. The perspective is stated baldly for Solomon Islands by Jennifer Corrin Care: "Human rights (particularly women's rights) and customary law embrace very different ideals. Customary law is based on male domination.... Human rights, on the other hand, are founded on principles of equality." ${ }^{\prime 3}$ Corrin-Care writes of "customary law" as though it somehow simply exists separate from the structures of colonial and postcolonial governance, a perspective widespread in the literature and one that radically simplifies complex and diverse gendered relationships. ${ }^{4}$ Understood not as timeless tradition but instead as part of a form of rule that Mahmood Mamdani calls "decentralized despotism," however, we can say that "custom" is based on male domination. Colonialism and Christianity often solidified men's authority over women and often profoundly transformed gender roles and relationships through a focus on the nuclear family. ${ }^{6}$ As Martha Macintyre notes, "Whatever the values attached to gender differences in the past, the differences that are now seen as 'traditional' form the basis for women's disqualification from the political, bureaucratic, and modern economic spheres." ${ }^{17}$ The opposition between custom and human rights that Corrin-Care refers to, then, is real at least insofar as a discourse of "custom" is frequently invoked to silence women's claims for equality, recognition and human rights in contemporary Melanesia.

Despite often-expressed concerns about the apparent incompatibility of custom and human rights, especially women's rights, the diffuse powers of global governance in a neoliberal age seem to be increasingly turning to "customary authority" as a panacea for problems of governance in so-called "weak" states. The trend is striking in those African nations where leaders of newly independent states rejected customary law as part of the architecture of colonial rule and attempted to eradicate it as part of modernisation projects in the 1970s and 1980s, but since the 1990s are increasingly re-authorising customary authority. ${ }^{8}$ This global trend is perhaps less noticeable in the Pacific

\footnotetext{
3 Jennifer Corrin-Care, "Customary law and women's rights in Solomon Islands," Development Bulletin 51 (2000): 20-22.

4 This sort of approach is critiqued by Margaret Jolly, "Woman Ikat Raet Long Human Raet O No? Women's rights, human rights and domestic violence in Vanuatu," in Human Rights and Gender Politics: AsiaPacific Perspectives, ed. Anne-Marie Hilsdon et al., London: Routledge Curzon, 2005, pp. 120-42.

5 Mahmood Mamdani, Citizen and Subject: Contemporary Africa and the Legacy of Late Colonialism, Princeton, NJ: Princeton University Press, 1996.

6 Margaret Jolly and Martha Macintyre (eds), Family and Gender in the Pacific: Domestic Contradictions and the Colonial Impact, Cambridge: Cambridge University Press, 1989.

7 Martha Macintyre, "'Hear us, women of Papua New Guinea!' Melanesian women and human rights," in Human Rights and Gender Politics: Asia-Pacific Perspectives, ed. Anne-Marie Hilsdon et al., London: Routledge Curzon, 2005, pp. 143-66, p. 148.

8 The resurgence of "the customary" in Africa has generated an extensive literature. See Helene Maria Kyed and Lars Buur, "Introduction: traditional authority and democratization in Africa," in State Recognition and Democratization in Sub-Saharan Africa: A New Dawn for Traditional Authorities? ed. Buur and Kyed, New York: Palgrave Macmillan, 2007, pp. 1-28; Juan M. Obarrio, “Remains: to be seen. Third encounter between
} 
because there was no comparable rejection of tradition: few leaders of newly independent states in the 1970s and 1980s rejected what came to be known as kastom, instead embracing kastom alongside Christianity as a constitutive pillar of postcolonial governance. ${ }^{9}$ A rhetorical embrace of kastom often went along with an erosion of the administrative structures that supported the neotraditional customary authorities that were constituted in the colonial period. This is particularly true in Solomon Islands, where, in contrast to neighbouring Vanuatu or Fiji, there is no national council of chiefs and, despite constant calls for decentralisation, government is and remains focused in the national capital of Honiara. Provinces are poorly funded and, since a reform mandated by structural adjustment policies of the mid-1990s, neither local courts nor local councils have functioned. ${ }^{10}$ In 1998, tensions between migrant Malaitans and indigenous people of Guadalcanal, the island where the national capital Honiara is located, broke into overt conflict, initiating a period of low-level civil war that lasted until 2003 when the Australian government initiated the Regional Assistance Mission to Solomon Islands (RAMSI). ${ }^{11}$ Ruling powers today - no longer a single colonial administration but a messy conglomeration of the Solomon Islands Government, RAMSI, bilateral aid donors, global aid agencies and others have sought to re-invigorate the customary authorities that are widely seen as having helped to hold the country together in an era of state collapse. This turn to the "customary" is part of a broader neoliberal approach to state building that seeks to strengthen non-state institutions rather than actually building state infrastructure. ${ }^{12}$ Focused primarily in Honiara and on Guadalcanal and Malaita (the two provinces most affected by the civil conflict), this re-emphasis on the customary is having a trickledown effect throughout the country.

\footnotetext{
state and 'customary' in northern Mozambique,' Cultural Anthropology 25 (2010): 263-300; Harry G. West, and Scott Kloeck-Jenson. "Betwixt and between: 'traditional authority' and democratic decentralization in post-war Mozambique," African Affairs 98 (1999): 455-84.

9 For collections of essays on the theme from different eras, see Roger M. Keesing and Robert Tonkinson, "Reinventing traditional culture: the politics of kastom in island Melanesia," (Special Issue), Mankind 13(4) (1982): 374-99; Robert J. Foster (ed.), Nation Making: Emergent Identities in Postcolonial Melanesia, Ann Arbor: Michigan University Press, 1995.

10 John Cox and Joanne Morrison, "Solomon Islands Provincial Governance Information Paper," Canberra: AusAID, 2004; Daniel Evans, Michael Goddard and Don Paterson, "The hybrid courts of Melanesia: a comparative analysis of village courts of Papua New Guinea, Island Courts of Vanuatu and Local Courts of Solomon Islands," Justice and Development Working Paper Series, The World Bank, 2011, online: http://www. worldbank.org/justiceforthepoor, accessed 23 February 2013.

11 See, e.g., Sinclair Dinnen, “A comment on state-building in Solomon Islands," Journal of Pacific History 42 (2007): 255-63; Jonathan Fraenkel, The Manipulation of Custom: From Uprising to Intervention in the Solomon Islands, Wellington, NZ: Victoria University Press, 2004; Clive Moore, Happy Isles in Crisis: The Historical Causes for a Failing State in Solomon Islands, 1998-2004, Canberra: Asia Pacific Press, 2004.

12 Matthew Allen, Long-Term Engagement: The Future of the Regional Assistance Mission to Solomon Islands, Australian Strategic Policy Institute, 2011.
} 


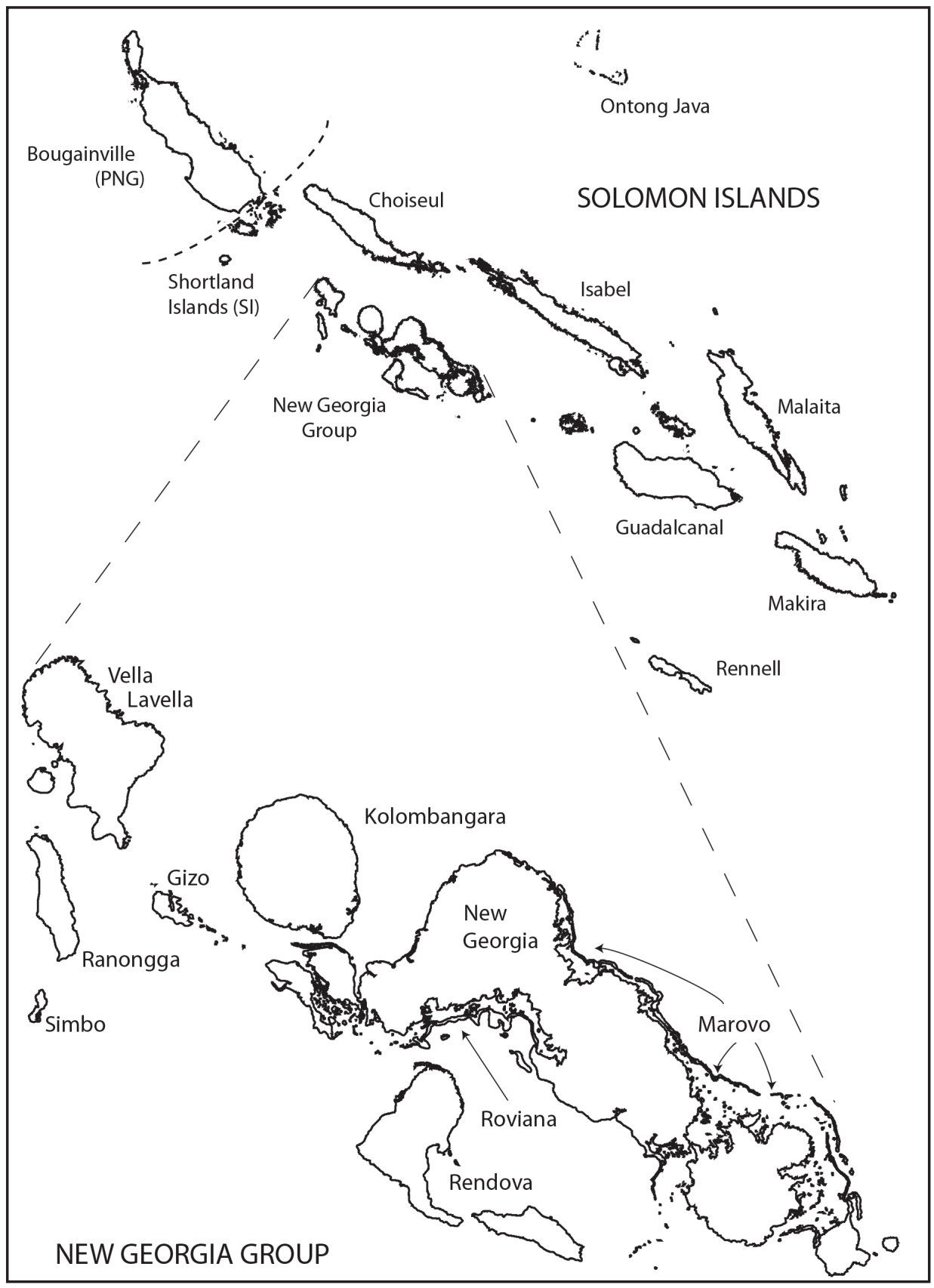

Map 1. Map of Solomon Islands, the New Georgia Group, and Ranongga Island

Source: Created by author from sources in the public domain. 
Current attempts to revitalise customary law resonate with colonial policies of indirect rule, but diverge markedly with regard to gender-a profound testament to the reach of the global feminist movement and its effects on global governance. Literature produced in the context of the intervention in the Solomons is pervaded by mantra-like invocations of the need to consider gender-few calls to recognise "customary authority" are not followed by some reference to the importance of "women's groups" and "church groups." Outsider attempts to promulgate a human rights agenda, however, may backfire and make indigenous women's struggles against gender violence and discrimination more difficult. As Margaret Jolly notes, "having powerful foreigners as allies risks alienating the very local men they are trying to influence and to change." ${ }^{13}$ Indigenous women who speak of women's rights, especially urban and educated women, become susceptible to accusations that they are merely parroting foreign discourses that are inappropriate for Melanesian situations. They must instead "operate within the small discursive space between anticolonialism and national pride." ${ }^{14}$ At the same time that outsider support of women's rights may invite nationalist opposition, however, the constant reiteration of the language of human rights seems to have normalised it. As I show below, phrases like "women's rights" and "human rights" have entered the lexicon of ordinary villagers in ways that may make the inclusion of women on such things as a chiefs' committee relatively uncontroversial.

This chapter explores emerging cracks in neo-traditional forms of patriarchy in a rural community on Ranongga Island, in the Western Province of the southwestern Pacific nation of Solomon Islands (Map 1). I begin by exploring precolonial precedents for women's customary authority over people and territory, power that was largely invisible to colonial authorities and absent from colonial records. I then consider the solidification of a domestic versus political sphere at the high point of late colonialism in the post-World War II years, focusing especially on Joyce Dunateko Panakera, a former Seventh-day Adventist who became Ranongga's first medically-trained female nurse and midwife and founded the islands' Methodist Women's Fellowship, and Dunateko's husband, Simion Panakera, a businessman and customary authority in the late colonial Solomons. Finally, I turn to the women now being incorporated into the Pienuna Chiefs' Committee in the 2000s, focusing especially on the experience of Marina Alepio, the daughter of Dunateko and Panakera, who was chosen to replace her brother as the "tribal" chief in 2005 (Figure 18).

13 Jolly, “Woman Ikat Raet Long Human Raet O No?" p. 129.

14 Martha Macintyre, "“Hear us, women of Papua New Guinea!'” p. 149. 


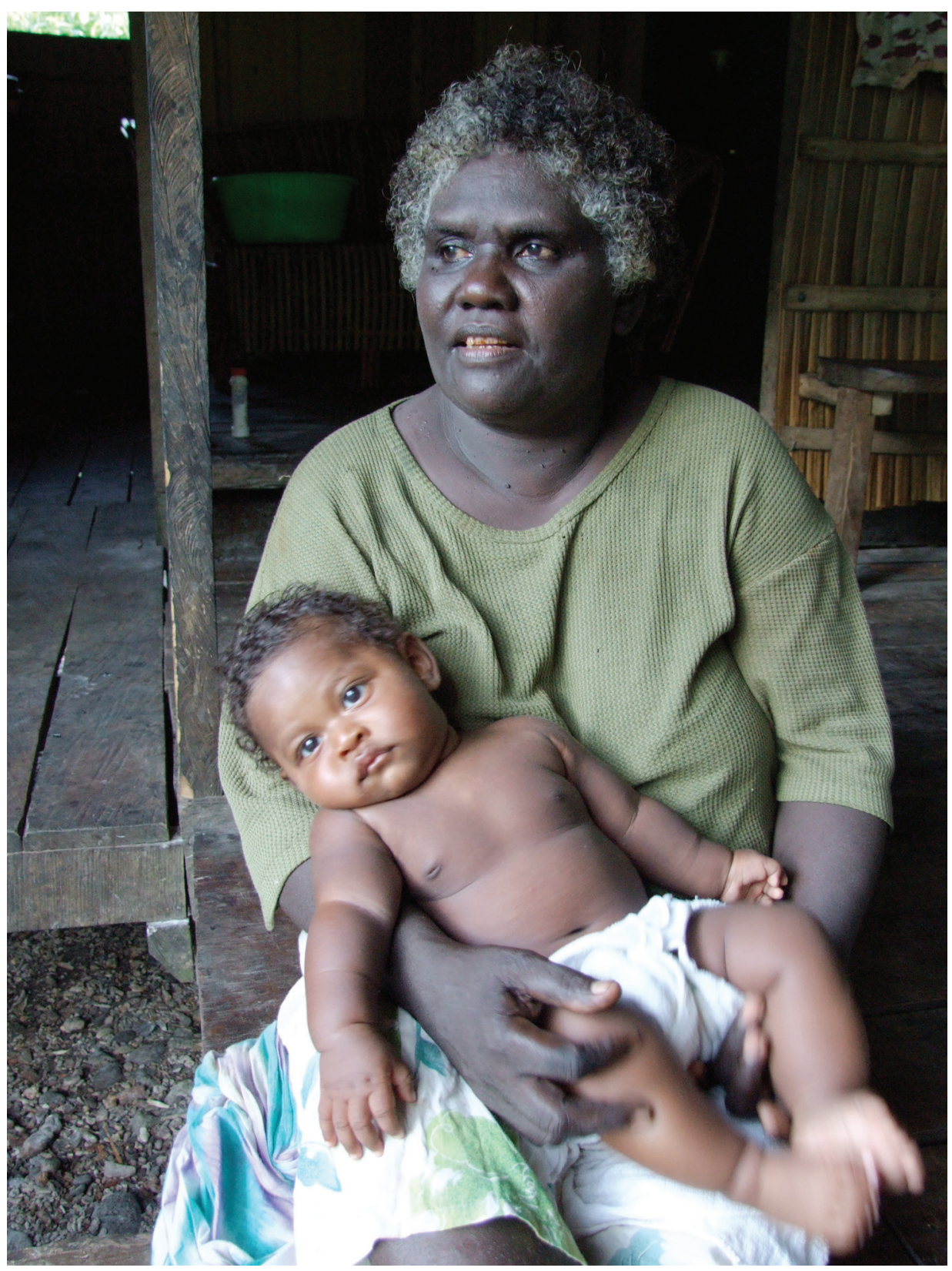

Figure 18. Marina Alepio with grandchild, Jericho village

Source. Photographer Debra McDougall, 9 December 2006. 
The recognition of female chiefs, the inclusion of women in chiefs' committees, and the often invisible leadership of women of previous generations belies any simple dismissal of "customary" institutions as inherently discriminatory. It points to the flexibility of local institutions and ingenuity of local people in responding to changing circumstances. At the same time, though, it is important to recognise that the customary authority that women like Marina are now taking on is greatly diminished from earlier in the century. Marina is a chief, but it is a chieftainship that has been "domesticated" by generations of colonial rule. Her work, like that of men in the same position, is focused primarily on maintaining amicable relationships within kin groups rather than engaging with powerful foreigners. The latter work is still mostly reserved for men, mostly educated urbanites who increasingly act as absentee landowners in negotiating resource deals regarding the land of their poor rural kinspeople. As Dickson-Waiko has argued, and Jemima Mowbray affirms in this volume, in contemporary Melanesia the "domestic" should be seen to consist not only of family households, but rural villages as a whole. Scholars write about the feminisation of labour markets in the industrial and industrialising worlds, where women seem more willing to take on lower-paid, less-secure, and lowerstatus positions that are replacing the secure employment of an earlier era. As the prestige and power of chiefs has declined and the focus of politicaleconomic power has moved beyond local shores, it is perhaps unsurprising that women are stepping into these roles.

\section{Gender and power in pre-colonial Ranongga}

Missionaries in the Western Solomons - like elsewhere in the colonial worldwere quick to underline the urgency of their work by describing what they saw as the utterly degraded position of women. The indigenous practice of widow suicide, whereby the wives of particularly high chiefs sacrificed themselves to accompany their husbands in death, was a favourite topic of the Reverend John Francis Goldie of the Methodist Mission (established in Roviana Lagoon in 1902) as well as other Protestant missionaries in areas where such practices existed. Missionaries like Goldie also saw the hard physical labour of women in gardens as a sign of their exploitation. In a representative comment, he wrote, "I have known cases where the female slaves have become the wives of their captors, and have been treated with as much consideration as the women belonging to the tribe - which is perhaps not saying much." ${ }^{15}$ As Bronwen Douglas' analysis of missionary discourse about women on Aneityum in Vanuatu suggests, such

15 John F. Goldie, "The People of New Georgia: their manners and customs and religious beliefs," Proceedings of the Royal Society of Queensland 22 (1908): 23-30, p. 27. 
a comment is stock-standard for the region and the era. ${ }^{16}$ Where they are mentioned at all, women appear in colonial and mission archives as wives and are often likened to servants and slaves.

Pacific Islands' women were not, however, only wives; they were also sisters, mothers, elders, persons of high rank or commoners, persons of particular clans. Among the most productive insights of late twentieth century studies of gender is the principle that one cannot begin analysis by assuming that "woman" will exist as a unified category in all situations. As Marilyn Strathern has argued influentially for Melanesia, we should focus instead on the gendered relationships that constitute both persons and exchange objects. ${ }^{17}$ The point is particularly important in attempting to imaginatively reconstruct the authority that women might have had in Pacific Islands' society before church and state more firmly delimited gender roles and realms. Drawing in part on Strathern's insights, and recent work on ranked societies in Vanuatu, Jolly argues that "graded societies" should be viewed "not as unchanging institutions, eternal manifestations of male kastom, but as diverse and dynamic processes of rank and power, responsive to, and constitutive of, indigenous and exogenous histories." ${ }^{18}$ Not only do women have parallel forms of exchange that give them status and prestige, but women may take rank in parallel or the same ceremonies.

By viewing women exclusively as wives, missionaries and colonial observers were especially likely to overlook the importance of the brother-sister relationship in many societies of Polynesia and island Melanesia, even as the policies they were implementing undermined sibling relationships. In her classic study of state formation in Tonga, Christine Ward Gailey argues that women as wives had lower rank than their husbands, but as sisters they had higher rank than their brothers; the kin relationships, not gendered bodies, determined status and power. ${ }^{19}$ The cross-sex sibling relationship remains critical in Ranongga and elsewhere in New Georgia. Prior to Christian conversion, it was believed that a transgression by a sister would cause her brother to die in warfare and a brother's transgression would cause the sister to die in childbirth; both were forms of " "bad deaths" that produced dangerous spirits rather than benevolent ancestors. Even today, sisters and brothers avoid physical contact and are not supposed to learn anything of the sibling's sexual relationships. Such forms of respectful avoidance are supposed to be reciprocal, and breaches may

16 Bronwen Douglas, "Provocative readings in intransigent archives: finding Aneityumese women," Oceania 70(2) (1999): 111-29.

17 Marilyn Strathern, The Gender of the Gift: Problems with Women and Problems with Society in Melanesia, Berkeley: University of California Press, 1988.

18 Margaret Jolly, "Material and immaterial relations: gender, rank and Christianity in Vanuatu," in The Scope of Anthropology: Maurice Godelier's Work in Context, ed. Laurent Dousset and Serge Tcherkézoff, New York: Berghahn Books, 2012, pp. 110-54, p. 114.

19 Christine Ward Gailey, From Kingship to Kinship: Gender Hierarchy and State Formation in the Tongan Islands, Austin: University of Texas Press, 1987. 
make sisters angry, but only brothers become violent if they hear of a sister's transgression and only brothers demand compensation. Drawing on historical sources and fieldwork in 1990-91, Christine Dureau documented how Christian ideologies of the family accorded husbands' authority over their wives and emphasised the role of "wife" rather than "sister" for women. ${ }^{20} \mathrm{~A}$ decade later in Ranongga, however, many incidents of gender-based violence I heard of or witnessed involved brothers and sisters, not husbands and wives - a testament, perhaps, to the ongoing importance of the cross-sex sibling relationship.

Like many other societies of island Melanesia, Ranonggan kinship could be said to be matrilineal. A person is of the butubutu (which I gloss as "clan" but which is often translated into English as "tribe") of his or her mother (though she or he is said to be "born of" the butubutu of her father). Although they are not localised, clans are defined in a large part through their association with homologous territories. Only a handful of the clans present on Ranongga are thought to have originated on the island itself; the others trace origins to other areas of New Georgia, Choiseul, Santa Isabel and, in rarer cases, to the eastern Solomons. Clan histories focus on female ancestors, their movement across the sea, and the divisions that emerged between sisters. Today, in written genealogies increasingly produced for the purposes of land disputes, women's names tend to be written in all capital letters and link the generations while men's names are written in small letters beside their sisters. Men, not women, are most likely to be omitted from genealogies and forgotten.

Unlike other parts of the Protectorate where chiefs were the invention of the colonial government, ${ }^{21}$ the islands that became known as the New Georgia group had a tradition of powerful chiefs (bangara) who could rally hundreds or thousands of men for the long distance war raids for which the region was notorious in the late nineteenth century. Archaeological research suggests that this chiefly complex began to emerge in the sixteenth century, when mortuary shrines became much more elaborate, and when long distance headhunting

\footnotetext{
20 Christine Dureau, "Nobody asked the mother: women and maternity on Simbo, Western Solomon Islands," Oceania 64 (1993): 18-35; Christine Dureau, "From sisters to wives: changing contexts of maternity on Simbo, Western Solomon Islands," in Maternities and Modernities: Colonial and Postcolonial Experiences in Asia and the Pacific, ed. Kalpana Ram and Margaret Jolly, Cambridge: Cambridge University Press, 1998, pp. 239-74.

21 Roger M. Keesing, "Chiefs in a chiefless society: the ideology of modern Kwaio politics," Oceania 38(4) (1968): 276-80. For recent discussions of the long-term transformations of chiefly leadership in connection to Christianity and the state written by anthropologists who have worked for decades in the region, see Edvard Hviding, "Re-placing the state in the Western Solomons: the political rise of the Christian Fellowship Church," in Made in Oceania: Social Movements, Cultural Heritage and the State in the Pacific, ed. Edvard Hviding and Knut Mikjel Rio, Wantage England: Sean Kingston, 2011, pp. 51-90; Geoffrey White, "Chiefs, church, and state in Santa Isabel, Solomon Islands," in Christian Politics in Oceania, ed. Matt Tomlinson and Debra McDougall, New York: Berghahn, 2013, pp. 171-97.
} 
warfare probably emerged. ${ }^{22}$ Islanders came into contact with European whalers on a regular basis in the early nineteenth century; a time of major epidemics due to introduced diseases. The introduction of iron tools seems to have lessened men's subsistence load, giving more time for other pursuits, including warfare which became more deadly with the introduction of iron and guns. Certain coastal chiefs in areas of high contact with Europeans were able to transform their relationships with Europeans into local prestige and power. The system was both at its peak and, because of depopulation, near collapse on the eve of British pacification in 1899-1900. ${ }^{23}$

Most bangara were men, yet mythic tales from Ranongga tell of female bangara who led or instigated war raids. This may reflect a practice in which a group (including men) are referred to by the name of a remembered clan ancestress (what Rumsey calls the " $\mathrm{I}$ " of discourse in the Pacific), whether or not she was directly involved in the raid. ${ }^{24}$ Even if few women were actually involved in leading raids, early ethnography and oral accounts suggest a well-established role for women in welcoming successful expeditions home. Several lineage narratives I heard, told of women who intervened to prevent the sacrifice of a captive in order to adopt the person, often as a "sister" for a son. ${ }^{25}$

These gendered roles are evident in stories of the arrival of Christianity. ${ }^{26}$ When young James Paleo of Pienuna accidentally boarded a mission ship and travelled to the headquarters of the Methodist Mission in Roviana Lagoon in 1914, his relatives took him for dead. Two years later, in 1916, he returned with fellow indigenous missionaries bearing the Bible. As these events are dramatised in Pienuna each year, Paleo was rebuffed by the male chiefs and ritual priests of the village who told him to leave and not "dirty" their sacred place. He was

22 Peter J. Sheppard, Richard Walter and Takuya Nagaoka, "The archaeology of head-hunting in Roviana Lagoon, New Georgia," Journal of the Polynesian Society 109(1) (2000): 1-37.

23 Judith A. Bennett, Wealth of the Solomons: A History of a Pacific Archipelago 1800-1978, Honolulu: University of Hawai'i Press, 1987, pp. 21-44, 112-15; Edvard Hviding, Guardians of the Marovo Lagoon: Practice, Place, and Politics in Maritime Melanesia, Honolulu: University of Hawai'i Press, 1996, pp. 79-130; John M. McKinnon, "Tomahawks, turtles and traders: a reconstruction in the circular causation of warfare in the New Georgia Group," Oceania, 45(4) (1975): 290-307; Geoffrey M. White, "War, peace, and piety in Santa Isabel, Solomon Islands," in The Pacification of Melanesia, ed. Margaret Rodman and Matthew Cooper, Ann Arbor: University of Michigan Press, 1983, pp. 109-40; Martin Zelenietz, "The end of headhunting in New Georgia," in The Pacification of Melanesia, ed. Margaret Rodman and Matthew Cooper, Ann Arbor: University of Michigan Press, 1983, pp. 91-108.

24 Alan Rumsey, "Agency, personhood and the "' $\mathrm{I}$ ' of discourse in the Pacific and beyond," Journal of the Royal Anthropological Institute (N.S.) 6 (2000): 101-15.

25 A first-hand account of women welcoming ashore captives in Simbo in 1903 is to be found in A.M. Hocart, "Warfare in Eddystone of the Solomon Islands," Journal of the Royal Anthropological Institute of Great Britain and Ireland 61 (1931): 301-24. Discussed in Debra McDougall, "Paths of pinauzu: captivity and social reproduction in Ranongga," Journal of the Polynesian Society 109(1) (2000): 99-113. For a comparative case, see Martha Macintyre, "Violent bodies and vicious exchanges: personification and objectification in the Massim," Social Analysis 37 (1995): 29-43.

26 Debra McDougall, "Fellowship and citizenship as models of national community: United Church Women's Fellowship in Ranongga, Solomon Islands," Oceania 74(1-2) (2003): 61-80. 
championed by Takavoja, a chiefly woman of butubutu Vitu, which held the land of Pienuna. Standing up to the men, she welcomed her "child" home and ushered him ashore to her house, where the first Christian services were held. In doing so, she seems to have been enacting the traditional role of chiefly women upon the return of a war canoe and is now credited, along with Paleo, with bringing the gospel to the island.

Takavoja also seems to have had considerable influence over plans for clan succession. ${ }^{27}$ Because she had no sisters, she is said to have been worried about the continuity of the Vitu clan - a worry that proved prescient because her only surviving daughter had no surviving daughters, so that her grandson (the current village chief) is the last Vitu man directly descended from the ancestress who established Vitu at Pienuna. According to the late Ruben Kiapio of Pienuna, Takavoja sent his father (a man of a clan named Kubongava whose land is in Choiseul) across the island to bring a sister back to Pienuna to act as her sister. There was an established relationship between Vitu and Kubongava that is linked to the original war raid that brought the first Kubongava woman as a captive to Ranongga. I was told that she was not taken as a "slave" but as a "replacement" for Vitu, which had called the raid. Kiapio's father and his cousins encountered Tuqetako with her mother in the bush harvesting taro and tricked the mother into allowing them to take her daughter. When they brought Tuqetako back to Pienuna, Takavoja is reported to have said, "If Vitu ends, then Kubongava can take over; she will be my clan replacement." In what must have been a marriage arranged to solidify this sibling-like relationship, the two women married two brothers. That means that the children of Takavoja and Tuqetako (including Simion Panakera, whose story I take up below) were siblings both because their mothers were (adopted) sisters and their fathers were brothers. Whatever the implications of such narratives will be for the chiefly succession at Pienuna, ${ }^{28}$ the story indicates the central role that Takavoja is remembered to have played in the affairs of this chiefly lineage and the ways that the "domestic" realm of marriage helped to solidify political alliances.

Takavoja's son, Alphaeus Toribule, was the village chief throughout the colonial era; her daughter, Mary Atunauru, also had significant authority over land and village life. Atunauru is remembered for donating a large and well-sited plot of land to a mission in the 1930s for a primary school, now the site of a junior high

27 Accounts that I have collected from elsewhere in Ranongga, including one recorded in the 1970s that recounted events of the 1880s and 1890s, suggest that women were called together to affirm decisions about male chiefly succession.

28 A grandson of Tuqetako was reportedly chosen to succeed the current chief of Pienuna, but he died unexpectedly at sea. His sisters' children have not yet demonstrated qualities of leadership that have made them obvious candidates for the position. The Vitu clan is not, moreover, extinct — only the lineage descended from Takavoja. During the period of my fieldwork, a powerful Vitu chief living in Vella Lavella sent his sister's daughter to live in Pienuna in order to re-establish the larger clan on its land, but she left after a series of conflicts. The situation remains unclear. 
school and teacher's houses. When Dunateko Panakera wanted to found the island's first women's Christian fellowship group - a story I take up in the next section - it was Atunauru whom she approached for permission. Importantly, though, this kind of female authority appears to have been completely invisible to both the colonial missions and the colonial administration, who saw only male authority. Toribule is visible in the archive as village chief and a member of the native court and council in post-World War II Ranongga; there is not a single reference to his sister. As women were excluded from the neo-traditional structures of native administration, their authority over land and people probably attenuated. At the same time, however, the church opened new spaces for women's collective action, not as sisters or chiefly women, but as women.

\section{Customary authority and a cult of domesticity}

Gender roles were transformed in twentieth-century Western Solomon Islands with a consolidation of male customary authority and female domesticity. This consolidation of men's and women's roles went together with and increasing emphasis on the importance of marriage, rather than siblingship, as the defining relationship in women's and men's lives and in the emerging economy of household-based cash cropping.

At the centre of Pienuna village is a large stone column with a marble plaque in memory of Joyce Dunateko Panakera "who pioneered the work of the UCWF (MWF) in Ranongga Island." Born and raised in Marovo as a Seventh-day Adventist, Dunateko (1914-1977) was trained as a nurse and midwife prior to 1942 (Figure 19). She was undertaking further training at the Adventist school at Kukundu on the island of Kolombangara when the terrifying power of global war exploded in the quiet backwaters of the Solomons. Behind Japanese lines in 1942-43, Kukudu became a base for the Islander coast watchers who radioed reports of Japanese movements to Americans. Among them was Simion Panakera (1902-1996) of Pienuna village, already a widower. Against the wishes of Dunateko's family, she eloped with Panakera, returned to Pienuna village, and converted to Methodism.

Even before the War, Panakera was becoming a powerful local leader and a person of influence within what was then the Western District of the British Solomon Islands Protectorate. As one of the first generation of young men educated through the Methodist Mission in Roviana, Panakera became a pastorteacher and was posted throughout the Bilua circuit in the 1930s. After the War, the British Protectorate administration worked to involve villagers in government through native courts and native councils. The three leading figures of this era were men identified with territorial divisions of the island: Panakera 
from Kubokota, George Hilly from Luqa, and Niqusasa from Ganoqa. Kubokota and Luqa were Methodist, but most of Ganoqa was Seventh-day Adventist and this area was sometimes referred to in government correspondence as the "SDA section." In 1948, a Native Administration and Native Court was established for the District Court of Vella Lavella District, which included Ranongga and Simbo, with Niqusasa as the founding Vice-President of both Court and Council. Toribule and Panakera alternated through the 1940s and 1950s as members of the council. When a separate court was established for Ranongga and neighbouring Simbo in 1957, Niqusasa was appointed its president, with George Hilly as the vice-president, and Panakera as one of the justices. ${ }^{29}$ During this period, these emergent leaders were also involved in mobilising land and labour for the commercial production of copra on Ranongga, sometimes as allies and sometimes as competitors. The two Methodists, in particular, were active entrepreneurs who acquired large areas of land, purchased copra from residents, ran large retail stores, and owned ships they used in these ventures. Panakera drew on the labour of his kinspeople and hired labourers from the eastern Solomons.

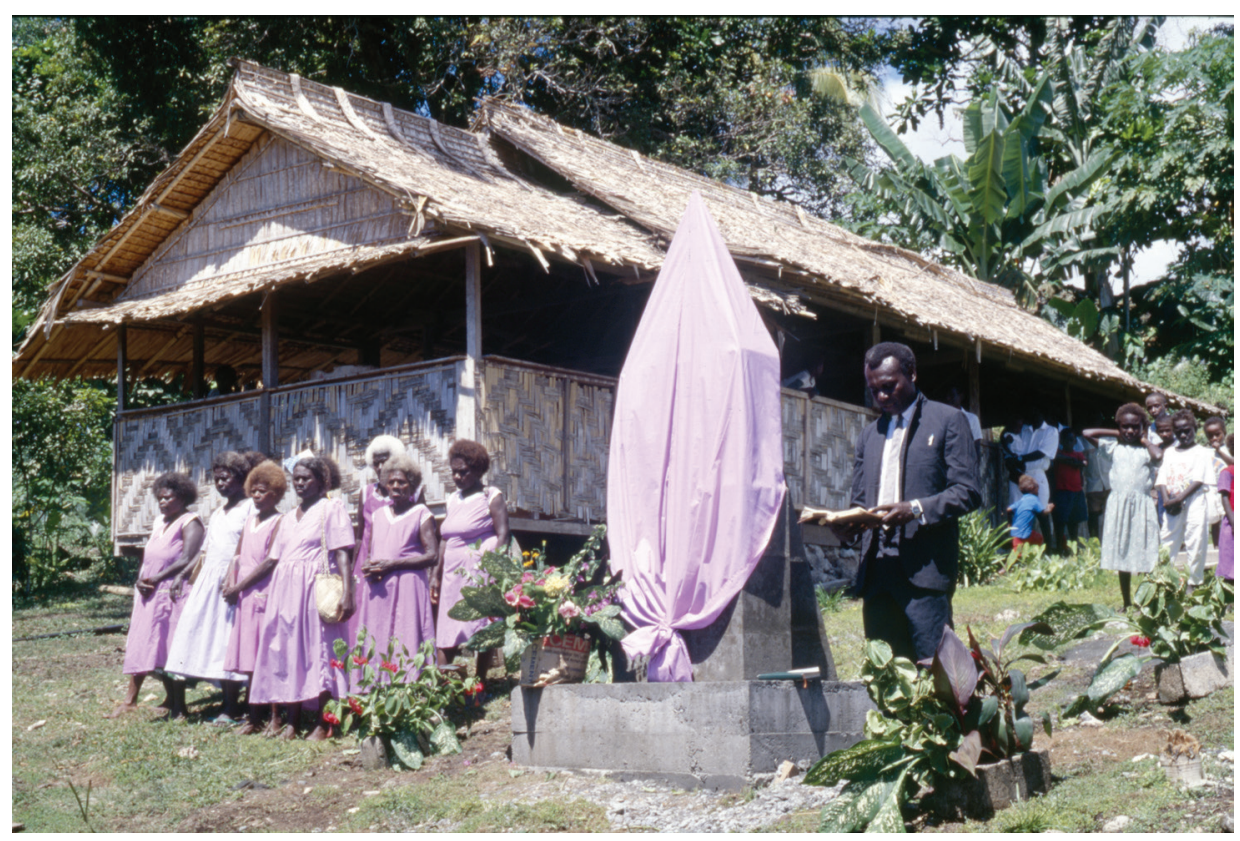

Figure 19. Pastor Joseph Sasapitu and members of the Ranongga United Church Women's Fellowship at the unveiling of a monument to the memory of Joyce Dunateko Panakera, 6 August 2000

Source: Photographer Debra McDougall, 6 August 2000.

29 BSIP 7/III/34/5, General Administration, Vella, 11 Nov 1948 and 9 Nov 1948. BSIP 7/I/DCW 124, Vella La Vella Native Council, 6 June 1957, National Archives, Honiara, Solomon Islands. 
If Panakera was at the forefront of neo-traditional male leadership, Dunateko established a certain model domesticity on the island. Dunateko's children and grandchildren remember her at the head of a bustling household. She had seven children with Panakera (including Geoffrey, Marina and Charlie to whom I return below) and also looked after children and grandchildren from Panakera's first marriage. Their hamlet was full of visitors, coming to see Panakera. She combined customary hospitality with modern sorts of order and cleanliness. If missionaries' insistence on clothing increased women's burden, this was a burden that Dunateko seems to have embraced. A detail of her domestic management that seemed as remarkable to her descendants as it does to me is the image of her starching and ironing the family's Sunday clothing every week! As Ranongga's first female trained nurse, Dunateko transformed practices of birthing on the island-working with a local midwife named Suluana, she normalised clinic births among a population of women who had until then refused the assistance of male nurses. ${ }^{30}$

The ideals of domesticity that emerged in Ranongga during the middle twentieth century were multiply paradoxical. As in the Papua New Guinea case that Jemima Mowbray discusses in this volume, colonial officials shared missionaries' belief that women's work in food gardens prevented them from dedicating themselves to home and nuclear family and that this demonstrated that indigenous men treated them as mere beasts of burden. Far from reducing women's subsistence burden thus "freeing" them for more appropriate domestic labours, however, colonial economic policies that pushed men into wage labour or encouraged cash cropping actually shifted more agricultural work onto women. In light of such analysis, Dunateko's success in emulating a certain Victorian model of domesticity should be understood in relation to Panakera's success in harnessing the labour of kin, hiring employees and accumulating capital. In the same way that middle-class women in early industrial Britain found it easier to live up to ideals of domesticity than working class women did, I imagine that Dunateko found it easier than ordinary women of Ranongga whose husbands controlled less labour or capital than Panakera.

When Dunateko came to Ranongga, she became a Methodist, but it is tempting to understand her particular form of domesticity as bound with her education within the Seventh-day Adventist mission. ${ }^{31}$ The "cult of womanhood" common to all Protestant missions seems to have taken root most strongly among Adventist

\footnotetext{
30 The dramatic improvement that trained midwives brought to women's lives in the second half of the twentieth century is hard to overstate. It is illustrated by the contrast between the reproductive histories of Panakera's first wife and Dunateko-whereas only four of his first wife's seven babies survived past early childhood and she herself died in childbirth, all of Dunateko's seven children survived to adulthood.

31 On differences between Adventists and other Christian denominations to modernity, see H. Jebens, "Beyond globalisation and localisation: denominational pluralism in a Papua New Guinean Village," Asia Pacific Journal of Anthropology 12(1) (2011): 91-110; Hirokazu Miyazaki, The Method of Hope: Anthropology, Philosophy, and Fijian Knowledge, Stanford: Stanford University Press, 2004; Harold M. Ross, “Competition
} 
communities. In the era of missionisation, Adventist missionaries differed from those of other churches in their overt rejection of many aspects of tradition and, unlike other missions and the government, they encouraged converts to take on European manners, dress and behaviours. Although European Adventists seemed disinterested in local culture, they were much quicker than their Methodist counterparts to ordain indigenous pastors and grant them extensive responsibility for evangelising other areas within the Solomons and PNG, often accompanied by their wives. ${ }^{32}$ As Dunateko's example suggests, by the 1930s even unmarried girls could undertake professional training, albeit in a field considered appropriate for women. On Ranongga today, Seventh-day Adventist villages appear neater than United Church villages, with a great deal of care taken in cultivating clover fields and flower gardens. Most have a higher proportion of timber and iron sheeting "permanent" houses to bush material houses than neighbouring United Church villages, signs of higher levels of participation in wage labour and investment of earnings into the household. Seventh-day Adventists regularly practise daily devotion in a nuclear family. An emphasis on education (with relatively high school fees) and greater degree of upward mobility has also made the nuclear family more important in Adventist communities than in United Church communities. ${ }^{33}$

Though an outsider, Dunateko seems to have quickly become a leader of Ranonggan women. In 1962, she was selected to attend a five-day training program for potential leaders of "women's clubs" led by an expatriate woman from the Honiara Women's Club and hosted by Marama Carter, the wife of the last expatriate New Zealand head of the Methodist Mission in the Solomons. Panakera paddled Dunateko across to the mission headquarters in Vella, where she joined three other women and travelled on the mission ship to Munda in Roviana. At the conclusion of the workshop, Marama Carter and the Methodist women decided to form not a women's "club" but women's "fellowship" and Dunateko returned with instructions to start such a group on her own island. As noted above, upon returning to Pienuna she consulted Mary Atunauru, the sister of village chief Toribule, who gave permission for this new enterprise. With the steadfast support of Panakera, who sometimes paddled and sometimes drove her in his new-fangled motorised canoe, Dunateko travelled around the island to spread the gospel of women's fellowship.

for Baegu souls: mission rivalry on Malaita, Solomon Islands," in Mission, Church, and Sect in Oceania, ed. James A. Boutilier, Daniel T. Hughes and Sharon W. Tiffany, Lanham MD: University Press of America, 1984, pp. 163-200.

32 Dennis Steley, "Unfinished: the Seventh-day Adventist Mission in the South Pacific, Excluding Papua New Guinea, 1886-1986," Ph.D. thesis, Auckland: University of Auckland, 1989.

33 Although Methodists and Adventists are interspersed and were closely related in the generation prior to conversion, interdenominational marriage was rare in the 1940s and today. Panakera is said to have really accomplished something by "stealing" a woman from the Seventh-day Adventists (SDAs). But Panakera himself had (and his descendants retain) close ties to Adventists relatives in Mondo (from where both his mother, Tuqetako, and his father, had come). 
In an earlier publication, I have described the foundation of Methodist Women's Fellowship, which became United Church Women's Fellowship (UCWF) in 1968, and the enormous importance it has in contemporary Ranonggan life. ${ }^{34}$ Initially dismissed as a waste of time (qurupu pavu goboro, in Pijin group taet nating, literally the "group that makes you tired for nothing"), by the early 2000s the UCWF was considered by village men and women a model organisation, better structured than the male-led church as a whole. With its emphasis on housekeeping and the Christian family, the UCWF and other similar organisations are hardly radical feminist organisations aiming to overturn gender inequalities. Dunateko herself emphasised that husbands were the head of the household and women should aim to help them raise a Christian family. ${ }^{35}$ But women's fellowship also drew women into a modern form of bureaucracy and new kinds of leadership that were not open to them through the path of male-only colonial native administration. Like Native Councils and Courts, Women's Fellowship had officers (President, Vice-President, Secretary and Treasurer), meetings, reports and formal training sessions. Women's fellowship accustomed women to public speaking, pushed them to take on formal leadership roles, motivated them to read, write and manage money.

Christian churches in many ways exacerbated existing patriarchal tendencies by reinforcing the power of husbands over wives and overlooking the other roles that women had in kin-based social organisation. Yet as Dickson-Waiko has argued, "It was churches which provided the opportunities and space for women to move out of their homes and into the public sphere"; women's church groups are thus "the missing rib" of indigenous feminism throughout the Pacific region. ${ }^{36}$ Women's church groups are often more effective and less subject to accusations of being seen as elitist than many secular initiatives more directly aligned with global feminism, yet this global feminism has profoundly shaped the local women's groups. Women's church leaders meet their counterparts from around the world and, often with male church leaders present too, they discuss things such as the UN 1975 Convention Against all Forms of Discrimination Against Women. The UCWF is a conduit for new sorts of ideas, which in the 1990s included ideas about human rights and women's rights. As I have documented, these global agendas are sometimes transformed dramatically in translation, but they nonetheless exist as discursive resources in discussions about the appropriate roles of men and women. ${ }^{37}$ This bottomup emergence of new kinds of female Christian leadership resonates with older

34 McDougall, "Fellowship and citizenship as models of national community."

35 Joyce Dunateko Panakera, "Autobiographical account of the origins of Women's Fellowship on Ranongga," n.d., manuscript received from Charlie Panakera in 2000.

36 Anne Dickson-Waiko, "The missing rib: mobilizing church women for change in Papua New Guinea," Oceania 74(1/2) (2003): 98-119, p. 103; see also other papers in Bronwen Douglas, Special Issue: 'Women's Groups and Everyday Modernities in Melanesia, Oceania 74(1-2) (2003).

37 McDougall, "Fellowship and citizenship as models of national community." 
forms of female traditional authority and, more recently, has dovetailed to some degree with top-down initiatives to include women as "stakeholders" in post-conflict nation building.

In the decades that women's fellowship groups were opening new avenues for women's collective action, colonial-era chiefs like Panakera increasingly lost control over the production of what remained the most important source of cash income well into the 1980s. The situation parallels that discussed at length by Robert Foster for Tanga Island in New Ireland. There, big men (whose authority was hereditary and affirmed through ritual) were instrumental in the mobilisation of labour and land for copra production. ${ }^{38}$ In the years after the Second World War, however, the control of big men was on the decline as individual households, often with unequal access to land and labour, undertook copra production independently. In Ranongga, a similar shift seem to have been caused by the increasing awareness of the processes of commercial production by ordinary people, the rise of government supported co-ops much smaller than those of Panakera and Hilly, and the increasing indebtedness of these entrepreneurs. Writing of Marovo, Edvard Hviding and Tim Bayliss Smith suggest that copra production "'democratised' access to wealth and status earlier this century because there was no aspect of the copra industry that could be brought under the sole control of local leaders." ${ }^{\prime 39}$ This was to change in the 1980s and 1990s as logging replaced copra as the most important source of cash income for many villagers and for the state as a whole. Male chiefs, and especially the savvy younger men who act as brokers in deals with logging companies and are increasingly acting as absentee landowners from positions in Honiara or overseas, have been able to consolidate power in a new way. The exclusion of women from realms of "customary authority" during the colonial era was reinforced in the context of the logging boom. In its uneven legislation and policy around logging, the independent government seems to have implicitly adopted colonially constituted understandings of traditional landownership. Most of the actual negotiations between companies and landowners occurred in male enclaves like hotels and often involved heavy drinking. Women were neither welcome nor would they have felt comfortable participating in such gatherings. ${ }^{40}$

\footnotetext{
38 Robert J. Foster, Social Reproduction and History in Melanesia, Cambridge: Cambridge University Press, 1995, pp. 42-50.

39 Edvard Hviding, and Tim Bayliss-Smith, Islands of Rainforest: Agroforestry, Logging and Eco-Tourism in Solomon Islands, Aldershot: Ashgate, 2000, p. 232.

40 Hviding and Bayliss-Smith, Islands of Rainforest, pp. 205-40. See also Judith A. Bennett, Pacific Forest: A History of Resource Control and Contest in Solomon Islands, C. 1800-1997, Cambridge: White Horse Press, 2000.
} 


\section{Gender, rights, and customary authority}

In 2005, Dunateko and Panakera's daughter Marina Alepio became the head of her extended family and a "tribal" chief in the context of customary village politics, succeeding her brother Geoffrey following his untimely death. As a senior woman and long-standing leader of the United Church Women's Fellowship, Marina had experience of leadership that she says has helped her in taking on the work of a "tribal" chief. As a church leader, she has long been called upon to mediate disputes through Christian prayer and counselling. ${ }^{41}$ Now she deals with different kinds of disputes - incest, adultery, swearing, threats of violence and fights about land - and helps to organise the exchange of money and valuables as compensation (ira) said in Ranongga to cool feelings and end disputes definitively. In the first years after Geoffrey's death, she had the unstinting support of a classificatory brother Jebeti Toribule (son of Toribule and grandson of Takavoja) who accompanied and supported her when she dealt with problems affecting the people for whom she was responsible. She participated in the work of the Pienuna Chiefs' Committee. Like other institutions of customary governance, this committee had been comprised only of men as chiefs but, in the processes of appointing new chiefs to replace those who had died, several women were chosen as chiefs, deputy chiefs or second deputy chiefs in the 2000s.

Like other apparently customary institutions, the Pienuna Chiefs' Committee is poised at the intersection of local and state forms of governance. ${ }^{42}$ The "customary" here must be understood in contrast to a law that it supplements but from which it has been excluded. The chiefs' committee emerged out of native and then local councils that were part of a colonial system of indirect rule that sought to harness traditional authority and traditional rules to state authority and state rule, while at the same time maintaining institutional and discursive divisions between custom and law. As in the African cases cited above, these colonially constituted forms of "custom" have experienced striking revivals in the context of decreasing faith in and commitment to states. As Michael Goddard points out, much of the voluminous literature generated in the wake of RAMSI has focused to some degree on a perceived lack of fit between customary and traditional approaches and state legal approaches to conflict and governance, with many recommending renewed efforts to reinforce those traditional institutions that maintained a reasonable degree of social order

\footnotetext{
41 Debra McDougall and Joy Kere, "Christianity, custom, and law: conflict and peacemaking in the postconflict Solomon Islands," in Mediating across Difference: Oceanic and Asian Approaches to Conflict Resolution, ed. Morgan Brigg and Roland Bleiker, Honolulu: University of Hawai'i Press, 2011, pp. 141-62.

42 A point that is well made in the introduction to an important volume on land tenure: James F. Weiner and Katie Glaskin, "Introduction," in Customary Land Tenure and Registration in Australia and Papua New Guinea: Anthropological Perspectives, ed. Weiner and Glaskin, Canberra: ANU E Press, 2007, pp. 1-14, online: http://press.anu.edu.au//apem/customary/html/frames.php, accessed 16 May 2014.
} 
in the face of state collapse. ${ }^{43}$ While it is usually acknowledged in passing that colonialism reshaped customary institutions, they are still treated as essentially indigenous and independent from the state. I suggest, in contrast, an institution like the Pienuna Chiefs' Committee is better viewed as the last remnant of a colonial system of indirect rule neglected by a postcolonial state.

In the era around and following national Independence in 1978, customary authorities existed in parallel to newer forms of democratically elected authorities. The men who served on Native and then Local Courts and Councils were not elected but appointed by the British administration; those serving on chiefs' committee today are selected by a range of informal procedures. When people of Ranongga and Simbo had the chance to elect representatives to the Provincial and National governments, the most prominent were the sons of colonial-era customary authorities. Francis Billy Hilly, son of George Hilly, was elected to the first Parliament in 1976 and, with a short break, served until he finally lost his seat in 2010, having held many Ministerial portfolios and served briefly as Prime Minister. Charlie Panakera, the son of Simion Panakera and Dunateko, was also elected to serve in the Provincial Government in the 1980s before he moved to New Zealand to take up a position as a university lecturer in management. In addition to National and Provincial levels, the 1981 Provincial Government Act gave provinces the right to establish "local area councils" as the lowest level of government instead of the previously unelected local councils.

Approaches to customary institutions - that is, those that were outside of the new structures of elected representation - in this early independence era were complex and contradictory. The explosion of logging on customary land ensured that the neo-traditional forms of customary leadership that emerged in the colonial period would remain vital. It also thoroughly compromised most levels of state government as officials found themselves on one or other side of land disputes and logging contracts. Like their colonial predecessors, however, independent legislators sought repeatedly to re-instate divisions between "custom" and "law." The Local Court (Amendment) Act 1985, for example, was an attempt to keep land disputes outside of the formal court system. It required that complainants try to solve grievances through the mediation of chiefs before approaching the local court. If the decision of these chiefs was not accepted, complainants could then appeal to the local court. Among the many problems with such a set up was that in most cases the very same men served as chiefs and

43 Michael Goddard, "Justice delivered locally Solomon Islands," Literature Review, Justice for the Poor, the World Bank, 2010, online: http://www.worldbank.org/justiceforthepoor, accessed 22 February 2013. Indicative of the turn to customary forms of governance is the fact that a major part of this World Bank program (undertaken in conjunction with Solomon Islands' Ministry of Justice and Legal Affairs) is focused on "Justice Delivered Locally" and aims at "invigorating local-level justice and governance systems." See Justice for the Poor, the World Bank, 2010, online: http://go.worldbank.org/PYYTF5A9K0, accessed 22 February 2013. 
local court justices. Although the legislation created the fiction that they were outside of government, they followed the same procedures that they, and their fathers before them, had learned to follow while serving on the local court. ${ }^{44}$ Thus, the hybrid systems of customary authority developed over decades of colonial government were artificially spliced between the government local court and the customary Chiefs' Committee.

Amidst rhetoric and policies favouring devolution of responsibility to provinces and area councils (especially with regard to logging), the state in the 1980s and 1990s withdrew support and recognition from all forms of local governance, both customary and democratically elected authorities. Instead of stemming the flow of land disputes to the formal court, the Local Court Act of 1985 merely added another layer of process: almost all decisions on the part of the chiefs were appealed to the court system. Overwhelmed and unfunded, local courts in Western Province through much of the 1990s simply did not sit except in situations where logging companies funded and organised hearings. Whereas earlier instantiations of native and local courts dealt with personal offences and even organised labour within villages, local courts in the 1990s focused entirely on land. In the context of structural adjustment policies of the 1990s, area councils - which were never very effective and quickly were sucked into the corrupt politics of the logging boom - were eliminated entirely. ${ }^{45}$

The withdrawal of state support and recognition did not, however, lead to the immediate demise of the Pienuna Chiefs' Committee. Building on the legacy of their fathers, men like Geoffrey Panakera, Jebeti Toribule, and many others continued their work without recognition or support from the state. The formal procedures of "chiefs' hearings" and the structure of formal officers such as president, vice, secretary, treasurer reflect the institution's origins in colonial era local courts and councils. The work of straightening disputes, however, did not proceed in the fashion of court cases, with much more emphasis on restoring amiable relations between the sides, affirming that everyone was related, and organising reciprocal forms of exchange of cash or shell money. As one of the stronger committees on the island, the Pienuna Chiefs' Committee was called to settle disputes all around the island, especially those involving conflicts over boundaries of cultivated areas and settlement sites and disputes around incest and adultery.

Even before the collapse of the state in the context of the civil crisis, the nongovernmental organisations (NGOs) that sought to combat destructive logging

\footnotetext{
44 "Chiefs' Hearings" (partial correspondence of Pienuna Chiefs Committee, 1986-1990), folder in possession of author.

45 John Cox and Joanne Morrison, "Solomon Islands Provincial Governance information paper," Canberra: AusAID, 2004.
} 
sought solutions to modern crises through a supposed return to "custom." On Ranongga, WWF (World Wide Fund for Nature) took an active role in attempting to reconstitute customary forms of community authority in the context of a conservation and development project commenced in 1997. An Australian consultant was retained in 1999 to produce a book of "custom law" and create a "peak body" of customary authorities (named the Ranongga Simbo Custom Council). Despite an overt emphasis within WWF's project on gender inclusion, the male consultant made no effort to include women, even those few who were recognised locally as clan leaders at the time. ${ }^{46}$ The following year, in the months following the June 5 coup, secessionist sentiment was running high in Western Province, which was at one point declared an independent state. The Premier and other officials were seeking to recognise and bolster the customary power of chiefs in rural areas, including Ranongga and Simbo, wanted to constitute a recognisable body with which it could work. I alerted Provincial authorities to the existence of the Ranongga Simbo Custom Council (which had not met since it was constituted by WWF). The (all-male) executive the Custom Council met with Provincial (or, as they understood themselves at the time, "State") authorities and employees of WWF. Provincial authorities encouraged self-sufficiency and the delineation of a clear local agenda but questions from the Chairman and members of the Ranongga Simbo Custom Council focused mainly on how chiefs can gain recognition and financial support from the government. Like all the others, nothing came of that meeting, which was (as far as I know) the last meeting of the Ranongga Simbo Custom Council.

By early 2007, the Chiefs Committee seemed to be at a low point. Several leaders had died and the young men who were designated their successors were disinterested in taking up their work. Jebeti Toribule, the Chairman of the Chiefs Committee, said that only Marina, who had replaced her brother the previous year, seemed eager to be mentored in learning the art of dispute settlement. Jebeti persisted in his efforts to seek broader recognition of the committee and was working on community by-laws he hoped would be ratified by the Provincial government. Yet his efforts seemed unlikely to bear fruit, and later in 2007, he left Ranongga to live in his wife's home area on the island of Santa Isabel.

When I returned for further fieldwork in 2010, I was therefore surprised to see that the Chiefs' Committee was meeting actively again and that several senior women were centrally involved. Of the twelve named "tribes" of the village, Marina was the only woman listed unambiguously as "tribal chief," with her sister as her deputy and her eldest son as the second deputy. Marina was also designated treasurer of the Committee. Three other women were listed

46 Debra McDougall, "The unintended consequences of clarification: development, disputing, and the dynamics of community in Ranongga, Solomon Islands," Ethnohistory 52(1) (2005): 81-109. 
as "deputy chiefs" for their tribes. Jebeti's sister, Varina Lekevolomo, became heavily involved in chiefly business after he left and she took over as secretary during meetings I observed in mid-2010. She effectively ran the meetings on behalf of the soft-spoken chairman, Luke Irapio (Figure 20). The inclusion of women on this committee is partially a response to external pushes for gender equity. In one June 2010 meeting, Varina said that the staff at the Peace and Reconciliation Office in Gizo asked her why she was the only woman on the Committee. Former Western Province Premier Reuben Lilo had been saying that Ranongga and Simbo had always had female chiefs. Silas Besa, a member of the Committee, pitched in to support the idea, saying that if there were two women, there should be two men; gender balance is important because women and men have different ideas. Derek Alekera, well-versed in the language of governance, added that it was also important for "equal rights" because "if we are not equal, then people do not have their human rights." In Pienuna, at least, there seems to be little resistance on the part of men to increasing the involvement of women, even an outspoken and ambitious woman like Varina.

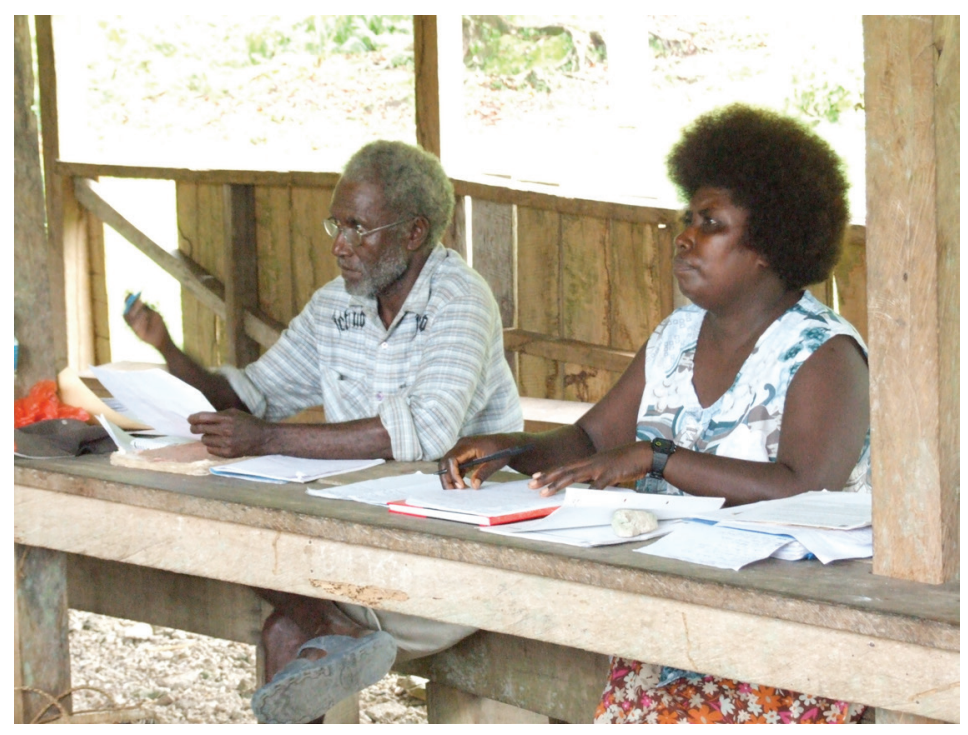

Figure 20. Luke Irapio and Varina Lekevolomo, Meeting of the Pienuna Chiefs' Trust Board

Source: Photographer Debra McDougall, 30 June 2010. 
The nature of this chiefs' organisation had, however, changed even in the decades that I have observed it. When I first was doing fieldwork in the late 1990s, the men who comprised the Pienuna Chiefs' Committee did not have formal meetings; they were called together in order to deal with specific disputes. In contrast, the series of meetings I witnessed in 2010 were centrally focused on the task of constituting the organisation in a way that it could be recognised by external authorities like the Provincial Government, RAMSI, and funding agencies. In a May 2010 meeting, the Pienuna Chiefs' Committee had been renamed the "Pienuna Chiefs' Trust Board," officer positions were designated and tribal chiefs were chosen to be signatories to the bylaws they would enact. The tribal chiefs were seen as part of a hierarchy of authorityfrom the family, to church, to tribal chiefs, to the chiefs' committee, to ward chiefs, and finally to provincial and government law. In other words, rather than exercising an already existing authority within local communities, the women and men focused on constituting chiefly authority in a bureaucratic form that would be recognised by outsiders.

In two day-long meetings in June and July 2010, which I attended, the focus was primarily on debating the "custom laws" which consist of a set of offences and penalties, built on the "Book of Custom Law" compiled in 1999 through the WWF project. Many participants had a sophisticated understanding of the boundary between custom and law. As David Alepitu, a former head of the Local Court, explained at one point, "The law aims to punish, but customary dispute resolution involves the exchange of money in order to 'smother' the problem and restore harmony." Varina, along with Derek Alekera, had attended workshops in Gizo on domestic violence and the rights of the child, and raised questions in the discussion about situations in which those offenses would have to be dealt with by both custom and law. In a discussion of an adultery case between a married man and an underage girl, Varina stated that they would be punished according to custom (which involves presentation of shell rings or cash by the family of offenders to those who are offended) and the Trust Board would also then report the man to the law for what amounted to statutory rape. Hours of discussion turned on the question of how to put a cash price on the traditional shell valuables used in compensation, valuables that are no longer produced and are too scarce to be used in every dispute. John Pavukera reminded everyone that those valuables were used, in the past, as substitutions for people who were to be killed, raising the inevitable question of the value of human life. Others argued for a token price because if the price was too high, disputes would linger as people worked to collect money.

Not only are women and men invoking the language of human rights and gender equity, and working on ways to reconcile the contradictory imperatives of community cohesion and individual freedom, but there seems little resistance to 
the increasing participation of women in what was formerly a male-dominated realm of neo-traditional authority. Yet even the brief overview provided here, however, suggests that an institution like the Pienuna Chiefs' Trust Board (like its predecessor, the Pienuna Chiefs' Committee) wields relatively little real power beyond local shores. In 2010 and prior years, much effort has been expended seeking recognition from more powerful authorities, a quest that has so far yielded little lasting success.

\section{The domestication of customary authority}

More than a century ago, A.M. Hocart's informants lamented the loss of chiefly power following pacification - without warfare, chiefs "stopped nothing" just like ordinary people. ${ }^{47}$ Chiefs like Panakera, Hilly and Niqu gained a new sort of power in the mid-twentieth century, but this power did not last more than a generation. In the 2000 meeting between the Ranongga Simbo Custom Council and representatives of the Provincial government and WWF discussed above, a member from Simbo said that the colonial government recognised chiefs and appointed them as headmen, but since independence, politicians have taken the real power and are antagonistic to chiefs. Chiefs are chiefs in name only, he said, without money or power to do their jobs. It was a lament I had heard frequently. "Tribal chiefs" in Ranongga have limited control over the labour of residents, limited power over land tenure and minimal engagement with multinational corporations seeking to undertake logging on the island.$^{48}$ Like church leaders, chiefs maintain harmony and good order in the village, which is now a fundamentally domestic sort of realm. In Ranongga at least, chiefs today manage the affairs of kin, but in a trans-local world where class divisions are coming to be more important than kinship ties, important decisions are often made far from the rural villages they affect. Marina occupies a very different sort of role than her father did fifty years ago, and not simply because she is a woman.

The emasculation of village chiefs is vividly depicted in a documentary, Since the Company Came, about the effects of logging on Rendova. ${ }^{49}$ It focuses on a village meeting, called by an old chief, to find out what is being done with royalty money. He talks of how many other projects have failed, and says he hoped that the logging that is now being undertaken by Kalena Timber Company will not also fail. Over the course of the meeting, the Chairman of the tribal development

47 A.M. Hocart, "Warfare in Eddystone of the Solomon Islands," Journal of the Royal Anthropological Institute of Great Britain and Ireland 61 (1931): 301-24.

48 Debra McDougall, "Church, company, committee, chief: emergent collectivities in rural Solomon Islands," in Managing Modernity in the Western Pacific, ed. Mary Patterson and Martha Macintyre, St Lucia: University of Queensland Press, 2011, pp. 121-46.

49 Russell Hawkins, Since the Company Came, video recording, New South Wales Film and Television Office, SBS Independent, Journeyman Pictures, 2003. 
corporation, a highly educated and articulate urban elite serving as Member of Parliament for the island, proceeds to harangue and humiliate this old chief, chiding him for being ignorant of modern accounting and accusing him of personal greed. The Chairman is briefly silenced by his father, who reminds him that it is not "customary" to fight over money and that the "company is not our brother." The meeting ends without any resolution, but the urban Chairman seems to emerge victorious, the village chief humiliated and disempowered. Women do not participate in the meeting, observing from the perimeter. The filmmaker interviews them about value of the land and their efforts to prevent logging on neighbouring Tetepare, which has been uninhabited for generations. One particularly articulate and apparently well-educated woman says, "Men are afraid to talk against other men. But we women can speak, on behalf of women and on behalf of men." The film conveys a sort of solidarity among the women but that overlooks the fact that women, as well as men, find themselves on different sides of land disputes, and many women are eager for forms of development that will lighten their subsistence burden. Insofar as they have been excluded from the nasty politics of land disputes in an age of logging and from the realm of formal government politics, however they are probably better empowered to speak for collective interests than men.

What may look like the movement of women beyond a colonially and missioninculcated domestic, can also be seen as the expansion of a feminised domestic realm. As being a village chief holds less and less prestige and power, women are increasingly taking on the often tedious work of sitting in futile meetings and the often thankless task of mediating disputes involving their relatives. This work is added to the other work for which they are responsible - subsistence gardening, copra production, market gardening, church work. And yet it is remarkable, and perhaps encouraging, that the neo-traditional patriarchy of customary authority in the village seems to be changing more quickly than the entirely modern patriarchy of elite circles of power. Women are no longer excluded from wage labour as they were in the colonial period; they are gaining entry into the civil service and some professions and some women are able to achieve some of their modest aspirations for independence and equality through waged work. ${ }^{50}$ Still, girls have far fewer opportunities for education, and therefore social advancement, than boys. Only two women have been elected to the Solomon Islands Parliament in the history of the nation (and the second was elected as a stand-in for her husband, jailed for criminal activities in the time of civil tension). ${ }^{51}$

\footnotetext{
50 Martha Macintyre, "Money changes everything: Papua New Guinean women in the modern economy," in Managing Modernity in the Western Pacific, ed. Mary Patterson and Martha Macintyre, St Lucia: University of Queensland Press, 2011, pp. 90-120.

51 Solomon Islands, Pacific Women in Politics, online: http://www.pacwip.org/future-elections/solomon-is/, accessed 23 February 2013; "Woman MP for North Malaita," Solomon Star, 03 August 2012, http://www. solomonstarnews.com/news/national/15560-woman-mp-for-north-malaita, accessed 23 February 2013.
} 
Increasing participation of women on chiefs' committees and other aspects of village politics is a positive development. There would be far more room for optimism, moreover, if the state would really extend itself into rural areas, engaging women and men, like Marina and others on the Pienuna Chiefs' Trust Board, in a sustainable and ongoing way to ensure that they are not really "tired for nothing." Whatever recognition of local leadership of men and women occurs, it is unlikely to amount to anything but a waste of time if it occurs only in donor-funded bursts of enthusiasm rather than the structure of a reliable state.

\section{Acknowledgements}

This paper draws on long-term research on the island of Ranongga undertaken in 1998-99, 2000-01, 2005, 2006-07 and 2010. I am deeply grateful for the assistance and friendship of Marina Alepio and all of the other children of Panakera and Dunateko, as well as John Pavukera, Jebeti Toribule, the late Samuel Samata, other men involved in the Chiefs' Committee, and the leaders of the United Church Women's Fellowship. I thank Chairman Luke Irapio, acting secretary Varina Lekevolomo and participants for allowing me to observe 2010 meetings of the Pienuna Chiefs Trust Board. In addition to ethnographic field research, I draw on archival materials from the Solomon Islands National Archives, in Honiara, which was the source for materials on colonial native administration in the Vella La Vella District of which Ranongga was part (BSIP 7/III/34/5 and BSIP 7/I/DCW 124). I also draw on materials in a folder recovered in 2007 from the residence of the late Geoffrey Panakera, the former Secretary of the Chiefs Committee, cited here as "Chiefs' Hearings" (partial correspondence of Pienuna Chiefs Committee, 1986-1990). Research was undertaken with the permission of the Ministry of Education and Human Resources Development in Solomon Islands and with support from the Australian Research Council (DP0666652), travel grants from the University of Western Australia, and doctoral research funding from the Social Science Research Council and Wenner-Gren Foundation for Anthropological Research. 
This text taken from Divine Domesticities: Christian paradoxes in Asia and the Pacific, edited by Hyaeweol Choi and Margaret Jolly, published 2014 by ANU Press, The Australian National University, Canberra, Australia. 